\title{
INTRODUCTION: FIVE DECADES OF GENDER IN JEWISH STUDIES
}

Where is gender in Jewish Studies and what does it mean? Labels send messages that result in selfselection but not always as intended by the sender. We chose gender because we assumed that it is now flexible enough to encompass methodological developments and individual preferences for feminism, women's studies, men's studies, gender studies, sexuality studies, and queer theory. The reader of this special issue, one of several similar recent stock-takes,' can gauge to what extent our efforts to capture such breadth have been successful.

The historiography of gender-sensitive study of Judaism encapsulates an interesting and ongoing dilemma of causality for the feminist movement: how do concepts and lived experience interact, and which of these should be the target for transformation? And indeed, is there a place for advocacy in scholarship?

Two early English-language pieces on Jewish religion and gender set this out, both first published in Davka, I mention this in order to signal the importance of dissemination platforms willing to support this work. In fact, Rachel Adler's "The Jew Who Wasn't There: Halacha and the Jewish Woman" appeared in a special issue of Davka on "The Jewish Woman" in 1971. Adler addresses halakhic scholars as change-makers; she is clear that inaction on their part should be countered with direct action: "the most learned and halachically committed among us must make halakhic decisions for the rest." Davka was not an academic publication, and it could be argued that Adler's piece does not belong in the historiography of Jewish Studies, but Jewish activism. Yet, its republication in the Brandeisbased Response: A Contemporary Jewish Review in 1973, again in a special issue on 'The Jewish Woman,' illustrates the embodied link between advocacy and academia in the field, a theme that recurs in the following papers. What is also a recurring, still necessary process is the corralling of gendersensitive approaches to Jewish Studies into special issues, a sign that mainstreaming has not yet been achieved.

The second early work to mention is Rita Gross' examination of gender in God language, originally published in 1976. Whether it is still essential to address this issue today or whether it is a purposeless distraction emerges as a point of contention in our later discussion of Jewish religious thought. When Gross reviewed her career in gender studies in religion, she stated: "It has taken me a long time to learn that telling the truth can exact a heavy price." "The truth" here refers to the development and application of research methods that do not omit, obscure, or falsify, something she helped to pioneer. Gross expressed her surprise about the resistance to such an endeavour. I suggest that there are at least two reasons for this resistance: first the perception that feminist gender studies in Jewish Studies makes patriarchy and by extension men look bad, and second that it makes Judaism look bad because it names its patriarchal aspects. Tal Ilan finds the latter to be a major stumbling block for gender-sensitive Jewish Studies today in environments where Judaism is to be protected. ${ }^{\prime}$ What Harry Brod (1994) theorizes as a double-bind in the wider social context mirrors the dynamic that Ilan describes in academia: solidarity as the collective's defence against hostility from the outside running in parallel with patriarchal oppression on the inside.

${ }^{1}$ E.g. Jewish Social Studies 24/2: 2019; see also the Oxford Summer Institute on Modern and Contemporary Judaism 2018: https://www.ochjs.ac.uk/wp-content/uploads/2018/01/Oxford-Summer-Institute-2018.pdf.

${ }^{2}$ Rachel Adler, “The Jew Who Wasn't There: Halacha and the Jewish Woman.” Reprinted in Response: A Contemporary Jewish Review (Summer 1973): 82.

${ }^{3}$ Rita Gross, "I am speechless: Thank you, colleague friends.” Buddhist-Christian Studies 31 (2011): 90.

"Tal Ilan, "Aufstieg und Niedergang eines feministischen Kommentars zum Babylonischen Talmud in Deutschland," in Andreas Lehnardt, ed., Judaistik im Wandel: Ein halbes Jahrhundert Forschung und Lehre über das Judentum in Deutschland, 149-59, (Berlin: De Gruyter, 2017).

She makes this claim in her examination of the state of Jewish Studies in Germany. At the centre of her account is the loss of funding for the feminist commentary of the Babylonian Talmud. Cecilia Haendler's article in this volume is related to this project. 


\section{The Sherman Conversations 2017}

Mindful of this ongoing problem, it was the intention of the Sherman Conversations 2017, an interdisciplinary day-conference at the University of Manchester's Centre for Jewish Studies, to offer a platform for unapologetic, constructive evaluation of the development and application of feminist method and theory over the last five decades, to interrogate what difference gender-sensitive approaches have made in a number of areas of Jewish Studies, and what the future outlook might be.

The day's proceedings modelled a feminist participatory process of conversations between all attendees, be they the authors of the starter papers, ${ }^{5}$ invited respondees and other participants. Arrangement in small conversation groups and rotation of panellists between these groups encouraged close encounters across generations, levels of scholarly seniority, depth of engagement with gender studies and feminism, and between adherents of different waves of feminism, if such demarcations indeed exist. It was in this intentional mixing that participants found new impulses for their work and an embodied sense that gender studies are a worthwhile pursuit.

Readers find in the first section of this special edition of Melilah the Sherman starter papers together with the formal responses. These are followed by a number of questions which were raised in the discussions. Thus, we invite readers into the Sherman Conversations in the hope that they continue beyond these pages.

The section opens with the transcript of the interview with Judith Baskin whose career spans the development of gender studies in a number of fields in Jewish Studies to date. Baskin's pioneer journey illustrates several recurring themes such as the embodied link between academia and social change in academics' lives, and the need for supportive platforms for collaboration and dissemination.

The progression from attention to women's experience through to queer theory is charted in Ruth Gilbert's survey of literary criticism. Gilbert recognises the affinities between queerness and Jewishness in their ambiguities and liminality. The response by Tamar Drukker continues the investigation of queerness as a stimulus for writing new social realities in the context of literary production in Israel.

Melissa Raphael reassesses feminist critique of the masculinity of God and biblical androcentrism in relation to social arrangements, and the resulting dilemma of how Jewish theology should move forward. She warns against the potential lack of community relevance of non-personal constructions of the divine. In her response, Lindsey Taylor-Guthartz examines efforts to prioritize biblical alternatives to masculinist images and language, and the potential of midrash as a traditional Jewish process of theologizing.

We pursue Rachel Adler's question of priority in the relationship between practice and theory further in Lisa Fishbayn Joffe's survey of Jewish law, here exemplified by the agunah issue. While earlier efforts to find a halakhic way focused on a gender-sensitive critique of law and the legal process, contemporary frustrations with lack of progress on the part of rabbinic authorities are channelled into jurisgenerative practices. However, as with other aspects of Jewish life, advances achieved in academia do not directly translate to adoption across Jewish communities, in fact they might lead to strongly defensive moves. Laliv Clenman's response brings to the surface yet again the spectre of systemic gender injustice: should it be uprooted or worked around?

\footnotetext{
${ }^{5}$ Starter papers were available in advance and only summarized on the day to maximise discussion time.

${ }^{6}$ These discussion points are based on the notes taken by Izabella Goldstein, Katharina Keim and Renate Smithuis.
} 


\section{Additional papers}

The responses to Melilah's open call for papers are in no way covering the whole disciplinary spectrum of Jewish Studies. They can only be indicative of the state of the art and future directions in a small range of fields.

The first paper mirrors the interview with Baskin in that it is also a personal reflection on a pioneer journey, here in the field of feminist Jewish Bible studies. Naomi Graetz weaves into the narrative of her geographical journey from North America to Israel significant people, publications and events in the feminist movement. She discusses the personal cost of others' perceptions of tension between her identity as a feminist and as religious. In her estimation, feminist Judaism might be 'dangerous' but ultimately constructive and hopeful.

The eternal challenge for feminists of how to face offensive gender discourse in rabbinic literature finds a subversive solution in Tali Artman Partok's suggestion to see the funny side of Genesis Rabbah 17. A Bakhtinian double-reading of this midrash goes against the grain of the expected reader response, and leads to the conclusion that it is a mockery of patriarchal ideology. Such a reading disproves the charge that feminist engagement with the tradition is a dead end.

Similarly, Cecilia Haendler's work demonstrates that gender-sensitive readings of rabbinic literature are by no means static and ideologically predictable. She examines Tractate Hallah as a narrative about the shifting intersection of sacred and domestic spaces, and the implications for the gendered division of ritual labour. What is highlighted here is the necessity for sophisticated genderliterate scholarship when working with material that carries complex gendered messages.

Methodological questions are pursued further in Etka Leibowitz' survey of the study of women in Antiquity. She traces developments in the ways historians have engaged with the representation of women, and shifting emphases in research since the nineteenth century. What past historians have examined is as telling as what they have ignored in women's life stories. Leibowitz highlights many such gaps in our knowledge of Antiquity waiting to be filled.

The representation of Jewish females is also the topic of Efraim Sicher's survey of contemporary British literature. Unlike the man-made representations in Antiquity, these are examples of Jewish women's creative production. Sicher considers the ways in which being Jewish and female in Britain highlights insider-outsider dilemmas where desire to defend Jewishness against hostile hegemonic culture clashes with the said hegemony's promise of women's empowerment from patriarchal restrictions of Jewish culture. Ultimately, gendered social change is not matched by new ethics needed to ensure justice, safety and self-determination.

What of the future? The pressing issue of bioethics responding to innovations in gender regimes and reproductive technologies is explored by Einat Ramon with a focus on Jewish conceptions of marriage and the family. Ramon calls for feminist Jewish theologians to review whether the concrete manifestations of post-gender thinking reintroduce the commodification of women and damaging gender relations. It seems more than apt to end this special issue by attending yet again to the relationship between theory and practice, the academy and the community.

Returning to the visibility of gender in Jewish Studies with which I opened, the Sherman Conversations brought to light a gap between student demand and staff expertise in the current British context. The mainstreaming of gender-sensitive, gender-focused and feminist approaches in Jewish Studies is still a project in progress. Where higher education is driven by the logic of demand, it might be timely to indicate gender studies more clearly in academic profiles, publications and course titles. That this is not widespread at present was brought home to us while searching for potential Sherman participants and for peer reviewers for articles submitted. Let us highlight and expand gender-sensitive provision so that these keen students can become the next generation of scholars and practitioners in the field.

${ }^{7}$ See Judith Baskin's reminiscence of Jacob Neusner in this volume. 
It poses a great challenge to represent the breadth of gender-sensitive studies in Jewish Studies through the cover image of this special issue. Much feminist Jewish artwork focuses on religion, and hence has a narrower remit than the following papers. Many images that show a range of human bodies contain nudity, which makes them unsuitable for this publication. I am delighted to be able to offer Jacqueline Nicholls' image "The Matrona" because it captures a recurring obstacle faced by gendersensitive researchers in many fields: who is allowed to participate in scholarly conversation and which questions are taken seriously? This textile work is part of the series Ghosts and Shadows: The Women who Haunt the Talmud. Nicholls writes:

Wives, sisters, mothers, daughters, prostitutes and maids - these women have no names and yet have an elusive haunting presence in the Talmudic texts. They often subvert the male rabbinic thinking, provide the countervoice and bring about changes in the narrative. With scant details they cast a shadow and assert their presence. These multi-layered embroideries quote the Talmudic text, and use the formal layout of the Vilna Talmud. But beneath those layers there are glimpses of the female form and hints towards their stories.

The Matrona: the one who was spurned for asking a question. This rich lady asked R. Eliezer a Torah question. He refused to answer her, saying that women's wisdom is in their spinning, and telling his students that Torah should be burnt rather than taught to women. She stopped being his patron. (Talmud Yerushalmi, Sotah $3: 4)^{m}$

The Matrona should take her patronage to The Centre for Jewish Studies where her question is most welcome. I would like to thank all who have contributed to this survey of gender in Jewish Studies. Special thanks are due to my co-editor, Renate Smithuis, and our assistant editor, Lawrence Rabone.

Katja Stuerzenhofecker

\section{BIBLIOGRAPHY}

Adler, Rachel. "The Jew Who Wasn't There: Halacha and the Jewish Woman." Response: $A$ Contemporary Jewish Review (Summer 1973): 77-82. Originally published in Davka (1971).

Brod, Harry. "Some Thoughts on some Histories of some Masculinities," in Harry Brod and Michael Kaufman, eds., Theorizing Masculinities, 82-96. Thousand Oaks: Sage, 1994.

Gross, Rita. "Female God Language in Jewish Context," in Carol P. Christ and Judith Plaskow, eds., Womanspirit Rising. A Feminist Reader in Religion, 167-73. San Francisco: HarperCollins, 1979. Originally published in Davka (1976).

Gross, Rita. "I am speechless: Thank you, colleague friends.” Buddhist-Christian Studies 31 (2011): 8999.

Ilan, Tal. "Aufstieg und Niedergang eines feministischen Kommentars zum Babylonischen Talmud in Deutschland,” in Andreas Lehnardt, ed., Judaistik im Wandel: Ein halbes Jahrhundert Forschung und Lehre über das.Judentum in Deutschland, 149-59. Berlin: De Gruyter, 2017.

\footnotetext{
${ }^{8}$ See: http://www.jacquelinenicholls.com/ghosts--shadows.html. Nicholls also contributed to the '50 Jewish Objects' project at the Centre for Jewish Studies, University of Manchester. Further information about this project can be found at: http://www.manchesterjewishstudies.org/50-jewish-objects-blog/
} 